\title{
Assessment of Internal Quality Management and Its Contribution towards Higher Education Excellence
}

\author{
Zahida Abro \\ Muhammad Zaki Rashidi
}

\begin{abstract}
Educational institutes are valuable assets of any nation. Education in general and higher education (HE) in particular is very important for socioeconomic growth of a country. Higher Education has different dimensions; it supplies human recourses, enhances scientific and technological advancement, provide new opportunities for research and development. Quality is an essentially required element at tertiary level educational institutions all over the world to promote excellence and bring the best practices. Universities have become more competitive and students and parents are in less compromising mood. They evaluate universities from different perspectives like fee structure, faculty, infrastructure and environment etc. The increasing demand of the stake holders has posed further challenges for the institutions to bring changes in the program designs, curricula, and adopt best practices available in that domain. This study attempts to evaluate the contribution of internal management policies to the higher education excellence. The study is cross-sectional and quantitative in nature. A structured survey is conducted to capture the perception of faculty and students' perception studying at post-graduate and PhD levels at Karachi. This survey has been considered as a quality lens through which effects of quality management has been analyzed. The data is collected by using quota sampling from private sector universities only, owing to the varied nature of internal management of these universities. The measurement tool is based on five-point Likert scale and comprises of two major subscales; quality management activities (QMA) and attention to quality aspects (AQA) taken as independent scales; whereas higher education excellence (HE) is considered as dependent variable. The data are coded and analyzed through SPSS software. It is concluded that overall perception of teachers and students for internal quality management and its contribution towards higher education excellence is positive. However, this varies among students and faculty while a variation is also found among various universities considered under this study.
\end{abstract}

Keywords: Internal quality management, higher education excellence, TQM, private sector universities.

\section{Introduction}

\subsection{Background of the Study}

Educational Institutes are valuable assets of any nation. They transform minds of youth by teaching learning and research activities (Maria et al. 2010). Higher Educational institutes are producing human resources for running business, industry and state. The skill, knowledge and ability the students acquire during the educational years open new windows towards development of a country.

Zahida Abro is lecturer at SZABIST Larkana Campus, abroo@Irk.szabist.edu.pk Muhammad Zaki Rashidi is Assistant Professor at SZABIST Karachi campus, zaki@szabist.edu.pk

\begin{tabular}{llll|l}
\hline Journal of Independent Studies and Research - MSSE & Volume 10 & Number 1 & January 2012 & 113
\end{tabular} 
Education in general and higher education $(\mathrm{HE})$ in particular is very important for socioeconomic growth of a country. Moreover, it makes countries prosper and be competitive. In this competitive age, only well educated societies can flourish who can adjust with the rapid HE has different dimensions; it supplies human recourses, enhance scientific and technological advancement, provide new opportunities for research and development changes in science and technology and that is only possible when our universities adapt new educational techniques and update curriculum to offer the courses blended with research.

According to Waseem (2007) higher education in Pakistan has been under the control of government after independence in 1947. The country got very weak physical infrastructure with insufficient funds to support educational institutes. From that time till the late eighties higher education remained under government control. In the nineties and even until the recent years, there has been a change in government policies to develop higher education due to establishment of private universities. The establishment of private universities gave opportunity to the government to re-organize its role as a sole operator in the country. Private universities have got space not only to share burden of government in terms of funds allocated for educational advancement in the country but also create competitive environment and new opportunities for development of education in the country. Despite all these efforts, the overall scenario of higher education in our country does not match with the global quality standards. We have a few universities, which to some extent are providing quality education and we can partially match these universities with worldwide educational standards. The standards include research publications, number of PhD faculty in a program, student-faculty ratio, integration of latest technology, employability are some of the main ones.

Quality is an essentially required element at tertiary level educational institutions all over the world focus on to promote excellence and bring the best practices. Initially quality was more an industrial concept rather than academic one. From industrial perspective, product is compared with the price to judge quality but when it comes to educational quality it is more abstract to operationalize the concept. However, it can be understood by considering different dimensions like academic quality; service quality and administrative quality etc. To evaluate higher education excellence upon these parameters require in-depth and careful study which gives insights to these institutes to meet stake holders' requirements. Quality in simple terms can be defined as to meet pre-determined standards set upon certain benchmarks in the particular industry. In case of educational institutes, these parameters are designed by internal management and external bodies as well.

For educational institutions quality may be judged from different dimensions for example academic achievements, research publications, peer group comparison, market share, qualified faculty, accreditation review, and modern computing and intellectual resources, research and scholarly contribution. Universities have realized that their long-term survival depends on how good their services are and that quality sets one university apart from the rest (Aly \& Akpovi, 2001; Kanji et al., 1999). Quality education has different perspectives; social perspective, where its contribution may be evaluated through students, parents and welfare of state. Economic perspective, students' services contribution towards GDP growth. Educationists contribute towards research and development also comes under education perspective.

$114 \quad$ January 2012 $\quad$ Volume $10 \quad$ Number $1 \quad$ Journal of Independent Studies and Research - MSSE 
Quality management in higher education is a continuous process. It requires proper planning, implementation and evaluation of the whole academic process to achieve desired results. QM consists of all activities carried within an institution according to the settled goals and strategies. It encompasses periodical assessment of the whole system by internal as well as concerned external bodies, teaching and learning assessment, students' intellectual development, research publications etc. Universities have become more competitive and students and parents are in less compromising mood; they evaluate universities from different perspectives like fee structure, quality and qualification of faculty, infrastructure support, congeniality of learning environment and location of campus etc. This leads to the challenge faced by the institutions, as the increasing demand of stakeholders has forced the institutions to bring changes in the programs and curricula (Longanecker, 1995). Maintenance of quality is essential for the survival of institutes. Some of the main reasons of maintaining quality are competition, customer satisfaction, institutes' prestige, accountability and sustainability etc. Internal quality can simply be defined as removal of all forms of waste; financial, physical, or human resources and bring efficiency in the overall system to achieve the set goals towards mission and vision of the institutions by satisfying all stake holders and creating value for the society.

\section{Literature Review}

Educational quality is considered as quality of teaching, learning and outcome according to the preset standards closest to the expectations of stakeholders. Aly and Akpovi (2001) points out that only those universities can survive for number of years who really care quality education more than their competitors. Quality concept in educational institutes as compared to industries is quite different (Harvey, 2007). Also universities differ in terms of quality because of the type of the organization, leadership, infrastructure and processes. Education is a complete process. Quality dimensions in higher educational institutions include but not confine to teaching, learning, infrastructure, faculty, examination system, resources, empathy and curriculum. Number of other dimensions may also be considered like goodwill of the institute, job hunting activities for students, recreational activities provided, research, students help in publications by the institutes, scholarships to needy students, healthy environment, empowerment to faculty and academic freedom (Rana, 2009).

Quality management encompasses the overall process to create teaching-learning environment as per (Grant et al., 2004). Quality management is a comprehensive process that includes input, processing and output by teaching and learning atmosphere. Parasuraman et al. (1991) concludes quality management aspects for service industry includes putting all resources into process which is carried out by the skilled people working in the organization and they also suggest courtesy, personal attention to the customers with pleasant moods. Jan Kleijnen et al. (2010) predicts a significant correlation between quality and its effects upon improvement of higher education, they find negative correlation between quality and management control.

Quality assessment is evaluation of the processes to check with the preset standards and achievements. Gates (2002) illustrated that many educational institutes develop self assessment standards to match quality of their services through students feedback and service outcome. Biggs (2003) comments quality assurance is related with the check of internal standards with the parameters of external bodies.

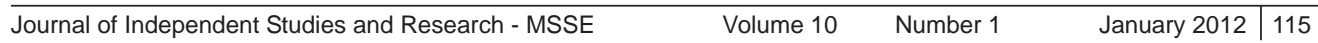


Quality assurance requires involvement and commitment at each level of activity carried out by employees to improve services performance. Quality assurance concept encompasses internal and external evaluation of a system. Quality assurance is a broad term as compared to quality assessment; the former one is taking external vigilance apart from internal and the later focuses internal evaluation only. Douglas and Douglas (2006) describe quality monitoring as encompassing students' feedback, internal evaluation of the system and external agencies involvement. Common approaches to quality assurance are IQM external quality monitoring (Harvey and Newton, 2007).

The quality measurement tools even applied to industries and educational institutes are facing controversy by different researchers like Don Houston (2007) who argues that applications of quality models and tools used by industries may not fit into frame of educational institutes. He suggested that higher education institutes must develop their own parameters to check the performance according to their stated goals. Koch (2003) contends the use of TQM in educational institutes except academics. Lumas (2007) argues that TQM is more industrial concept and it cannot be fully applied to service sector, especially educational institutes.

A specific model can be applied as per organization's own requirements which can suit and may give them better results to improve and reach at the top of the particular industry they operate in. For service sector like educational institutes, the standards should be measured through the tools which are specifically developed for service units. Moreover, organizations may develop their own parameters to check their services. Johnston (1995) stated that most frequently used theory to measure service quality is disconfirmation theory and the same is supported by other researches (Walker, 1995), who explained confirmation, negative disconfirmation and positive disconfirmation aspects of theory.

Students perceive quality in terms of cost and benefits out of the services provided by institutions which is another way to measure quality. Students are service receivers and hence they can better judge quality of services they receive. They directly observe the delivery of lectures, methodologies, management support, environment and other facilities (Becket and Brookes, 2005).

\section{Theoretical Framework}

In this study, the variables have been taken from a study conducted by Jan Kleijnen et al. (2010), which are PDCA, internal evaluation, teaching and learning, information and facilities and perceived improvement. These variables are measured to evaluate internal quality management and its effects upon higher education excellence. All these variables are the part of two sub-scales QMA (quality management activities) and AQA (attention to quality aspects). The effect of the scales dimensions upon higher education has been developed though conceptual framework. The relationship of the independent variables of sub-scales like PDCA (plan, do, check and act), internal evaluation and communication, teaching and learning, information and facilities towards perceived improvement will be measure under the head of operational framework. Based upon that, fifteen hypotheses have been developed to test. The expected relationship between independent and dependent variable is positive (unidirectional hypotheses) that is witnessed in the literature review that if institutions pay more attention towards teaching and learning, planning, timely information and proper facilities, check and balance then perceived improvement will also increases and it directly contributes towards higher

116 January 2012 $\quad$ Volume 10 Number 1 Journal of Independent Studies and Research - MSSE 
education excellence. This means that if independent variables increases or decreases the effect will tend to move in the same direction. Therefore, the relationship has been considered positive. Operational framework is given below to show the relationship between variables through schematic diagram:

\section{Operational Framework}

PDCA

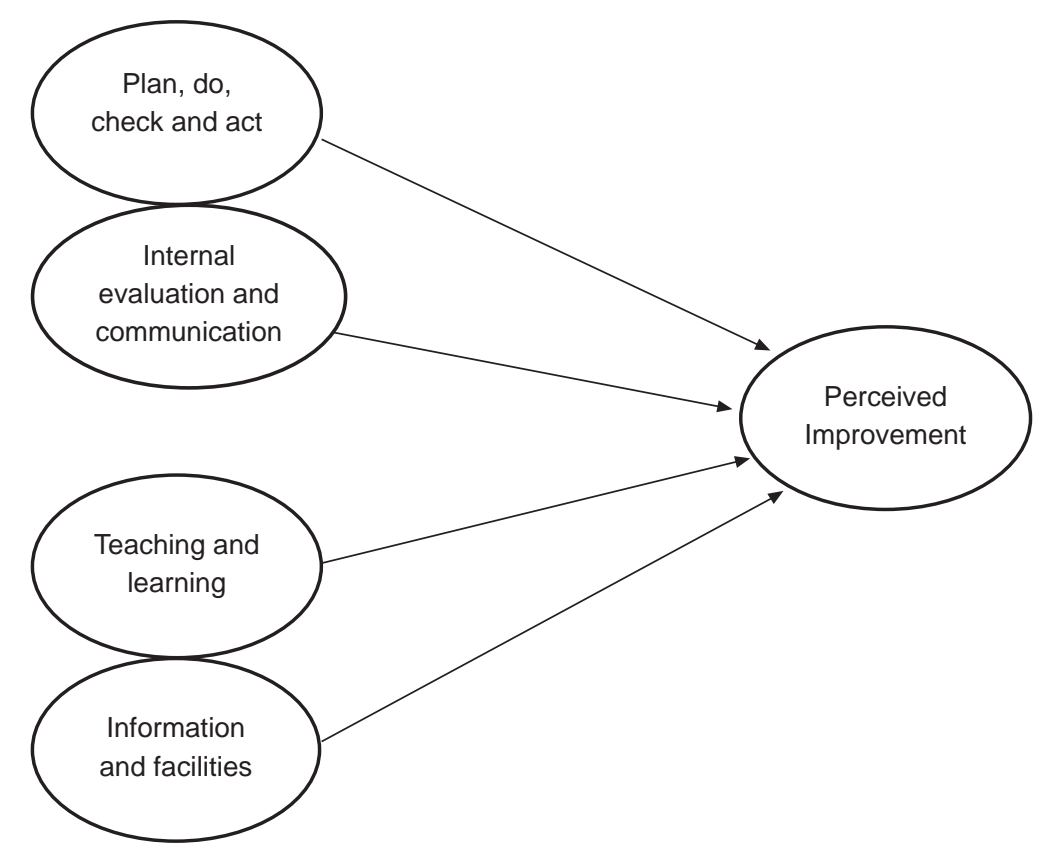

Operational Framework is split picture of Theoretical Framework carrying four independent variables of QMA and AQM scales (two from each scale) and their effect upon dependent variables shown in the diagram mentioned above. This framework shows that perceived improvement in higher education excellence depends upon Plan, Do, Check, Act (PDCA), internal evaluation and communication, teaching and learning, information and facilities.

\section{Research Methodology}

This research is quantitative and cross-sectional in nature and data is collected through primary and secondary data sources. Permanent faculty and regular students of four private universities will be focused. Students enrolled in Masters/MS/PhD programs are considered for data collection. A sample of 400 students and 100 faculty members will be selected on proportional basis from these universities by using quota sampling. An instrument of data collection is used in "Does internal quality managementcontribute to more control or to improvement of higher education: A survey on faculty's perceptions" by Jan Kleijnen et al is used. The scale is based on Likert scale ( 1 = fully disagree and 5 = fully agree, where as 3 = neutral). Scales (QMA and AQM) contains following variables to evaluate internal quality and its contribution towards Higher Education 
Excellence: internal evaluation, PDCA (plan, do, check and act), teaching and learning, information and facilities, and perceived improvement.

\section{Data Analysis and Discussions}

\section{Teachers' and Students' Quality Perception}

\begin{tabular}{|l|c|c|c|c|c|}
\hline & $\mathrm{N}$ & Minimum & Maximum & Mean & Std. Deviation \\
\hline PDCA & 460 & 1.00 & 5.00 & 3.3826 & .74193 \\
\hline $\begin{array}{l}\text { Teaching and } \\
\text { Learning }\end{array}$ & 460 & 1.00 & 5.00 & 3.4609 & .76652 \\
\hline $\begin{array}{l}\text { Information and } \\
\text { Facilities }\end{array}$ & 460 & 1.00 & 5.00 & 3.5491 & .75847 \\
\hline $\begin{array}{l}\text { Perceived } \\
\text { Improvement }\end{array}$ & 460 & 1.00 & 5.00 & 3.5217 & .75223 \\
\hline Internal Evaluation & 460 & 1.00 & 5.00 & 3.1543 & 1.27831 \\
\hline
\end{tabular}

The descriptive analysis of the respondents reveals that overall perception of teachers and students for internal quality management and its contribution towards Higher Education Excellence falls at agreed side for dependent variable Perceived Improvement (i.e. 3.5 on a scale of 1 to 5 , where $1=S D$ and $5=S A$ ). In case of all independent variables, same trend has been found. Standard deviation has found less than 1.0, which shows that there is less variance in respondents' response.

\section{Relationship among Variables}

\begin{tabular}{|l|c|c|c|c|c|}
\hline & PDCA & $\begin{array}{c}\text { Teaching and } \\
\text { Learning }\end{array}$ & $\begin{array}{c}\text { Information } \\
\text { and Facilities }\end{array}$ & $\begin{array}{c}\text { Perceived } \\
\text { Performance }\end{array}$ & $\begin{array}{c}\text { Internal } \\
\text { evaluation }\end{array}$ \\
\hline PDCA & 1 & $.606^{* *}$ & $.553^{\star *}$ & $.534^{* *}$ & $.442^{* *}$ \\
\hline $\begin{array}{l}\text { Teaching and } \\
\text { Learning }\end{array}$ & 1 & $.631^{* *}$ & $.541^{* *}$ & $.488^{* *}$ \\
\hline $\begin{array}{l}\text { Information } \\
\text { and Facilities }\end{array}$ & & 1 & $.505^{* *}$ & $.394^{* *}$ \\
\hline $\begin{array}{l}\text { Perceived } \\
\text { Performance }\end{array}$ & & & & 1 & $.360^{* *}$ \\
\hline $\begin{array}{l}\text { Internal } \\
\text { evaluation }\end{array}$ & & & & & 1 \\
\hline
\end{tabular}

** Correlation is significant at the 0.01 level (2-tailed). The data contains 460 respondents $(\mathrm{N}=460)$

Combined data containing responses of 460 respondents shows that all correlations are significant at 0.01 level of significance. The highest correlation is found between Teaching and Learning and Information and Facilities, whereas, the low correlation (.394) is found between Internal Evaluation and Perceived Performance. This shows that relationship between internal evaluations towards dependent variable requires to be strengthened in higher education institutes. 
Impact of Teachers' and Students' Perception

Model Summary

\begin{tabular}{|l|c|c|c|c|}
\hline Model & $\mathrm{R}$ & R Square & $\begin{array}{c}\text { Adjusted R } \\
\text { Square }\end{array}$ & $\begin{array}{c}\text { Std. Error of } \\
\text { theEstimate }\end{array}$ \\
\hline 1 & $.619 \mathrm{a}$ & .383 & .377 & .59360 \\
\hline
\end{tabular}

ANOVA

\begin{tabular}{|l|c|c|c|c|c|}
\hline Model & $\begin{array}{c}\text { Sum of } \\
\text { Squares }\end{array}$ & df & Mean Square & F & Sig. \\
\hline Regression & 99.405 & 4 & 24.851 & 70.528 & $.000^{a}$ \\
\hline Residual & 160.322 & 455 & .352 & & \\
\hline Total & 259.727 & 459 & & & \\
\hline & & & & & \\
\hline
\end{tabular}

a. Predictors: (Constant), Internal evaluation, Information and facilities, PDCA, Teaching and Learning

b. Dependent Variable: Perceived

Coefficients

\begin{tabular}{|l|c|c|c|c|c|}
\hline Model & \multicolumn{2}{|l|}{ Unstandardized Coefficients } & $\begin{array}{c}\text { Standardized } \\
\text { Coefficients }\end{array}$ & $\mathrm{t}$ & Sig: \\
\hline & $\mathrm{B}$ & Std. Error & Beta & & \\
\hline (Constant) & 1.053 & .152 & & 6.945 & .000 \\
\hline PDCA & .266 & .050 & .262 & 5.348 & .000 \\
\hline $\begin{array}{l}\text { Teaching and } \\
\text { Learning }\end{array}$ & .230 & .052 & .235 & 4.390 & .000 \\
\hline $\begin{array}{l}\text { Information } \\
\text { and Facilities }\end{array}$ & .189 & .049 & .191 & 3.851 & .000 \\
\hline $\begin{array}{l}\text { Internal } \\
\text { Evaluation }\end{array}$ & .032 & .025 & .054 & 1.257 & .209 \\
\hline
\end{tabular}

a. Dependent Variable: Perceived Improvement

Dependent variable, perceived improvement, is explained by independent variables, PDCA, information and facilities, teaching and learning and internal evaluation by $37.7 \%$. Hence the "perceived improvement" depends on some other factors that are not considered in this study. This show that the model fit is not good. The factors PDCA, Teaching and Learning and Information and Facilities are significant, while Internal Evaluation is insignificant. The contribution of PDCA and Teaching and Learning factors is higher as compared to other two factors. Also Internal Evaluation factor is not contributing more towards Perceived Improvement. 


\section{Key Findings}

- The descriptive analysis of the respondents reveals that overall perception of teachers and students for internal quality management and its contribution towards Higher Education Excellence falls at agreed side for dependent variable Perceived Improvement (i.e. 3.5 on a scale of 1 to 5 , where $1=\mathrm{SD}$ and $5=\mathrm{SA}$ ).

- Teachers' Perception for the dependent variable Perceived Improvement comes at satisfaction side with (3.4) scores. This indicates that teachers are of the opinion that IQM contributes towards HE excellence.

- Students have been more agreed with the mean score of (3.5) for dependent variable as compared to the independent variables; PDCA, Teaching and Learning Information and Facilities as well as Internal Evaluation with the mean scores of $(3.3,3.4,3.4$ and3.0) respectively. This indicates students are also of the opinion that IQM contributes towards HE excellence.

- All correlations are significant at 01 level and the highest correlation is found between Teaching and Learning and Information and Facilities. Whereas, the low correlation (.394) is found between Internal Evaluation and Perceived Performance. This shows that relationship between internal evaluations towards dependent variable requires to be strengthening in Higher education Institutes.

- Regression analysis shows dependent variable, perceived improvement, is explained by independent variables, PDCA, information and facilities, teaching and learning and internal evaluation by $37.7 \%$. Hence the "perceived improvement" depends on some other factors that are not considered in this study. Keeping this in view, we may say the model is not good fit.

- Coefficients in Regression analysis shows the factors PDCA, Teaching and Learning and Information and Facilities are significant, while Internal Evaluation is insignificant. This indicates that Internal Evaluation factor is not contributing more towards Perceived Improvement.

- Regression split file for Teachers and students' shows dependent variable, perceived improvement, is explained by independent variables, PDCA, Information and facilities, teaching and learning and internal evaluation by $68.4 \%$. Hence, the "perceived improvement" also depends on some other factors not considered in this study. This show in case of teachers Model fit is good.

- In case of students this is not considered as good fit Model because adjusted R square shows $31.5 \%$ dependent variable perceived improvement, is explained by all four independent variables.

\section{Conclusion and Recommendations}

\subsection{Conclusion}

The data analysis and findings provide insight and we can conclude that overall perception of teachers and students for internal quality management and its contribution towards Higher Education Excellence is positive towards perceived improvement. Faculty perception based upon independent variable scale testing shows AQA scale has contributed more as compared to QMA scale. One of the variables of QMA scale "internal evaluation" has been found insignificant in case of teachers and students individual opinions. Teachers' and students' opinions differ while comparing variables correlation. From teachers' perspective, teaching and learning has high correlation with perceived improvement, whereas students were of the opinion that teaching and learning

$120 \quad$ January 2012 $\quad$ Volume $10 \quad$ Number $1 \quad$ Journal of Independent Studies and Research - MSSE 
has high correlation with information and facilities. Overall results compared with individual outcomes of teachers and students regarding internal quality management and its contribution to higher education indicate the direction of the opinion of teachers and students vary regarding independent and dependent variables correlations. Students' opinion is more dominated while we compare their individual perception with overall results in terms of independent variables influence upon dependent variables. In all four universities, majority of the students were found in Masters level program, $\mathrm{PhD}$ students were hardly found. Teaching faculty was dominated with a majority of lecturers.

\subsection{Recommendations}

Internal evaluation requires to be strengthened in higher education institutes; student and faculty's perception plays a vital role in internal quality assessment of the university hence universities and higher education institutions should seek their perception periodically to bring quality in higher education. 


\section{References}

Aly, N., \& Akpovi, J. 2001, 'Total Quality Management In California Public Higher Education', Quality Assurance in Education, Vol. 9 No.3, pp. 127-31.

Andre, W. \& Bukaza 2009, 'Applicability of the high-performance organization framework at an East African university', International Journal of Emerging Markets, Vol. 6 No. 2, pp. 148-167.

Biggs, J. 2000, Teaching for Quality Learning at University, Open University Press, Buckingham.

Becket, N. \& Brookes, M. 2006, 'Evaluating Quality Management In University Departments', Quality Assurance in Education, Vol. 14, No. 2, pp. 123-42.

Becket, N., \& Brookes, M. 2005, 'Analyzing quality audits in higher education', Oxford Brookes University e-Journal of Learning and Teaching, Vol. 1, No. 2, pp. 1-22

Cave, M. Hanney, S, Henkel, M. \& Kogan M. 1997, The Use of Performance Indicators in Higher Education: The Challenge of the Quality Movement', Jessica Kingsley, London.

Gates, M. Augustine, C, \& Benjamin, R, 2002, 'Ensuring quality and productivity in higher education: An analysis of assessment practices', ASHE-ERIC Higher Education Reports, Vol. 29 No. 1, pp. 1-171.

Jackson, M. C. 2000, Systems Approaches to Management, Kluwer Academic/Plenum Publisher, New York, NY.

Kleijnen, J., et al., 2010, 'Does internal quality management contribute to more improvement of higher education? A survey on faculty's perceptions', Quality Assurance in Education, Vol. 19, No. 2, pp. 141-155

Koch, J. V. 2003, 'TQM: why is its impact in higher education so small?', The TQM Magazine, Vol. 15, No. 5, pp. 325-33.

Longanecker, D. 1995, 'High performance higher education: The federal role', Thought and Action: The NEA Higher Education Journal, Vol. XI, pp. 105-110.

Lomas, L. 2007, 'Zen, motorcycle maintenance and quality in higher education', Quality Assurance in Education, Vol. 15, No. 4.

Madu, C. N., \& Kuei, Chu-Hua, 1993, 'Dimensions of quality teaching in higher institutions,' Total Quality Management, Vol. 4, No.3, pp. 325-338.

Maria et al., 2010, 'Evaluation of the factors that determine quality in higher education: an empirical study', Journal Of Quality Assurance in Education, Vol.18, No. 3.

Owlia, M. S. \& Aspinwall, E. A. 1996, 'Quality in higher education', Total Quality Management, Vol. 7, No. 2, pp. 161-71.

122 January 2012 $\quad$ Volume $10 \quad$ Number $1 \quad$ Journal of Independent Studies and Research - MSSE 
Parasuraman, A., Zeithaml, V., \& Berry, L. L. 1985, 'A conceptual model of service quality and its implications for future research', Journal of Marketing, Vol. 49, pp. 41-50.

Parasuraman, A., Berry, L. L. \& Zeithameln, V. A. 1991, 'Refinement and reassessment of the SERVQUAL scale', Journal of Retailing, Vol. 67, No. 4, pp. 420-50.

Sahney, S, Banwet, D. K. \& Karunes, S. 2004, 'Conceptualizing total quality management in higher education', The TQM Magazine, Vol. 16. No. 2, pp. 145-59.

Segers, M. S. R. 1993, Quality Assurance in Higher Education: An Explorative Inquiry into the Performance Factors in Theory and Practice, University of Maastricht, Maastricht.

Vroeijensteijn, A.I. 1995, Improvement and Accountability: Navigating between Scylla and Charybdis: Guide for External Quality Assessment in Higher Education, Jessica Kingsley, London.

Van Damme, D. 2004, 'Standards and indicators in institutional and programme accreditation in higher education: A conceptual framework and a proposal", in Vlasceanu, L. and Barrows, L.C. (ed), Indicators for Institutional and Programme Accreditation in Higher/Tertiary Education, UNESCO-CEPES, Bucharest, pp. 127-59.

Wiklund, H., Klefsjo", B., Sandvik Wiklund, P. \& Edvardsson, B. 2003, 'Innovation and TQM in Swedish higher education institutions: possibilities and pitfalls', The TQM Magazine, Vol. 15, No. 2, pp. 99-107. 